DOI: $10.2478 / \mathrm{v} 10025-010-0029-2$

JOURNAL OF WATER

AND LAND DEVELOPMENT

J. Water Land Dev. No. 13a, 2009: 205-223

\title{
The effect of environmental conditions on surface water quality in the Zimnik and Czyrna catchments of the Beskid Śląski
}

\author{
Stanisław MAŁEK, Katarzyna KRAKOWIAN
}

Agricultural University in Cracow, Department of Forest Ecology, Forest Faculty, al. 29 Listopada 46,31-425Cracow, Poland, e-mail: rlmalek@cyf-kr.edu.pl,krakowian.k@gmail.com

\begin{abstract}
The study was carried out in the year 2004 in the Zimnik and Czyrna catchments situated on opposite slopes of Skrzyczne in the Beskid Śląski Mts. Water samples collected from streams during three sampling sessions were analysed. The first session was carried out during snowmelt (April/May), the second during intensive rainfall in the vegetation season (June) and the third - during low water level (October). A data set consisting of conductivity, water $\mathrm{pH}$, concentrations of major anions $\left(\mathrm{Cl}^{-}, \mathrm{NO}_{3}{ }^{-}, \mathrm{SO}_{4}{ }^{2-}\right)$ and cations $\left(\mathrm{NH}_{4}{ }^{+}, \mathrm{Na}^{+}, \mathrm{K}^{+}, \mathrm{Ca}^{2+}, \mathrm{Mg}^{2+}\right)$ was produced and waters were then classified according to Polish standards (years 2002 and 2004). Chemical composition of stream waters depended on physical and geological properties of drainage areas and on seasonal changes of water level in the catchment. Water class depended also on precipitation and on forest type. It was found that water from most sampling points in streams was unfit for drinking -66 out of collected 89 samples were beyond the first A1 category and the main reason for that was too low $\mathrm{pH}$ and high concentrations of $\mathrm{NH}_{4}{ }^{+}$and $\mathrm{NO}_{3}{ }^{-}$. During intensive rainfall in the vegetation season higher washing out of cations was observed from beech and multispecies forest stands than from spruce stands, which partly neutralized water $\mathrm{pH}$ and in consequence improved water quality. This phenomenon should be considered while afforesting streams neighborhoods where water is or will be used as a source of drinking water.
\end{abstract}

Key words: Beskid Ślaski Mts., forest type, geology, species composition, surface water, water quality

\section{INTRODUCTION}

Numerous publications describe the impact of environmental conditions on chemical properties of waters in different regions (DYNOWSKA, 1986; CHEŁMICKI et al., 2001; KOSTARKIEWICZ, 2001; MICHALCZYK, 2001; SIWEK, 2004). According to ZDANOWICZ (1994) and ŻMUDA (1994) the process of water self-purification runs best in mountain streams, where fast current ensures permanent oxidation. Moreover, in mountain regions the sources of rivers are often located within the 
borders of forests, which affects water quality and increases its retention as it is the case in the Beskid Śląski. Structure of geological profile, type of rocks and forest influence the chemical composition of outflow waters. It was found, that in mountain areas the release of minerals weathering from the rock substratum may be a dominant factor responsible for chemical composition of outflowing waters (MUNK and FAURE, 2004; TRUdGiLl et al., 2004). Moreover, biological processes in the soil layer or in stream water may play significant role (WRÓBEL, 1998). Chemical composition of spring water depends strongly on the type of soil and geological profile and on plant cover, surface configuration and even on slope exposition (MAŁEK and GAWĘDA, 2004; 2006a; 2006b; MAŁEK and KRAKOWIAN, 2007). One of the factors which determine the content of inorganic compounds in surface waters is seasonal variability of water level in the catchment (SZCZESNY and ZIĘBA, 2001). Quantitative and qualitative analyses of surface waters were done in order to find the effect of long lasting spruce monoculture on physical and chemical water properties. The paper is part of the hydro-chemical description of waters in the Beskid Śląski systematically monitored within the scope of activity of the Department of Forest Ecology at the Agricultural University in Cracow (MAŁEK and GAWĘDA, 2004; 2006a; 2006b; MAŁEK and KRAKOWIAN, 2007). Unfortunately, the chemical composition of surface water was not evaluated in a complex way that would consider: geological conditions of the catchment area, prevailing forest stands, seasonal variability of water level and other environmental factors in particular catchments. This is the reason why we decided to apply multivariate environmetric techniques to surface waters in order to verify the hypothesis whether the chemical composition and drinking water quality class of streams located in the Zimnik and Czyrna catchments depend on physico-geological structure of drainage areas.

\section{STUDY SITE}

The study was carried out in part of the Zimnik and Czyrna catchment located on slopes of Skrzyczne (1257 m a.s.l) - $49^{\circ} 34^{\prime} \mathrm{N}, 18^{\circ} 50^{\prime} \mathrm{E}$ - above the level of building development. Waters in the Czyrna catchment flow into the Żylica that has an outlet in Lake Żywieckie - a dam reservoir on the Soła River. Waters from the Zimnik catchment flow to the Leśnianka River which is the left side tributary to the Soła. Those two rivers belong to the Wisła drainage basin. Point no. 46 " $\mathrm{Li}$ powa" of the Regional Monitoring of Underground Waters is located in the study area. Waters of the region are of calcium-bicarbonate-sulphate type (PACHOLEWSKI et al., 2004). According to the administration division of State Forests, Skrzyczne is located within the borders of the Regional Directorate of National Forest in Katowice, Forest Division Węgierska Górka, Forest Circle Lipowa, Forest District Skrzyczne, and Forest Division Bielsko, Forest Circle Szczyrk, and Forest District 
- Skalite and Czyrna. These areas are situated within the Forest Promotion Complex "Beskid Śląski Forest" and in the natural reservoir of Beskid Śląski (Plan..., 1998-2001; Plan..., 2004-2013).

The area is classified into the Interior Western Europe, Carpathians subarea, Sub-Carpathians, and Valleys, the Carpathians and Sub-Carpathians province, Exterior Wester Carpathians subprovince, Beskidy Zachodnie macro-region, Beskid Śląski mesoregion according to physical and geographical regional divisions by KONDRACKI (2000) (internal code: 513.45).

Present topographic profile of the Beskid is mainly a result of erosive activity of running waters. Large falls create energetic erosion deepening the valleys; whereas, at the outlet of streams there are plains of intermountain valleys. An important role in structuring the profile have slopes and valley landslips that occur due to undercutting of slopes by water erosion or to slipping of sandstones on waterlogged slates (MAŁEK and GAWĘDA, 2004; 2006a; 2006b; MAŁEK and KRAKOWIAN, 2007; www.wsa.bielsko.pl). Skrzyczne (1257 m a.s.1.) is the highest summit of the Beskid Śląski; Barania Góra also belongs to this range (KONDRACKI, 2000).

Podzols, cambiosols and regosols dominate in the geological formations. Soils in the Czyrna catchment are more fine-grained than those in the Zimnik catchment (map 1). The podzolization process of soils was probably, like in other regions of the Beskid, intensified by improper activities, in particular due to "spruce-mania" (MACIASZEK et al., 2000).

Location of habitat types of forests in the two catchments reflects their connection with the climate, elevation and exposure (map 2). In the Czyrna catchment due to north or north-west slope exposition we have mixed mountain forests (LMG) and mixed mountain coniferous forests (BMG) (for explanation see map 2). Those forest types reach lower parts of the catchment. Moreover, there is also spruce monoculture forest type not present in the Zimnik catchment. In the latter, forest habitats are composed of fir and beech, which are lacking in Czyrna.

The majority of spruce communities surveyed by WILCZEK (1995) was assigned to fir-spruce forest of lower subalpine forest, which indicates habitat disturbance or even degradation (over $40 \%$ of disturbed habitats in the Czyrna and Zimnik catchments are mixed mountain forests). Moreover, there is still a tendency of diminishing water resources on mountain slopes and deteriorating of water quality in streams (DORDA, 2004). As a result of "spruce-mania" foresters are currently dealing with the problem of spruce dying out, which is also present in the study area.

\section{METHODS}

Sampling sites were selected in each stream from spring till the outflow to the other stream. In the Zimnik catchment 20 points and in the Czyrna catchment 18 points were selected (maps 1, 2, 3). Sampling was performed in three sessions: I- 


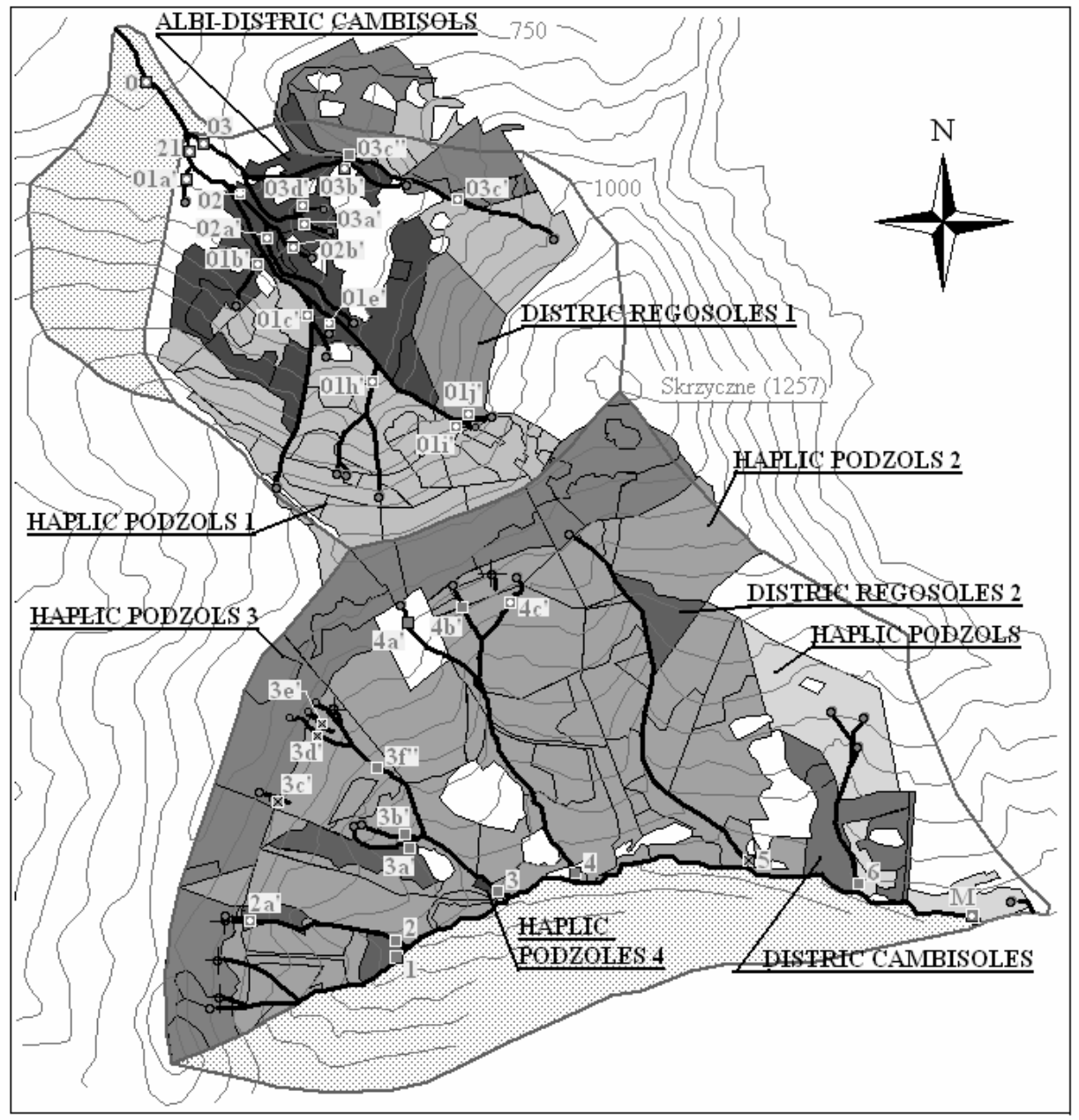

\section{Legend}

- Springs

Water quality class

- Drought springs

- I class

Contour lines

$\wedge$ Streams

II class

$\checkmark$ III class

$\times \Gamma$ class

- V class

Soil grain composition

1 dust on stony-clayey-loamy deposits

2 colluvial sands on stony-gravely deposits

3 dust on stoney-gravely deposits

4 fomerly arable ground, colluvial sands on stony-gravely deposits

Map 1 . Soils in the study area and water quality classes during the intensive rainfall 


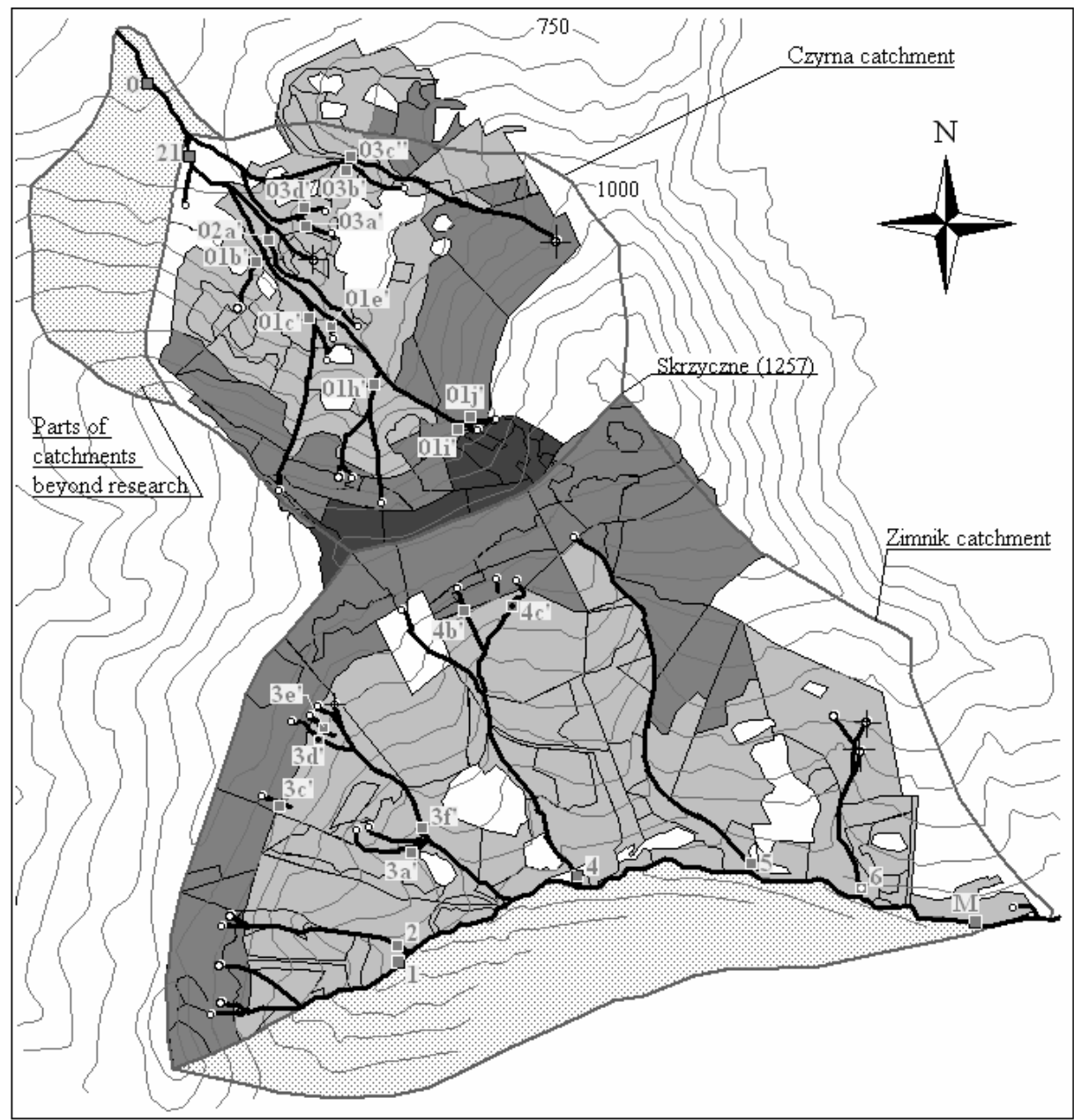

\section{Legend}

- Springs

- Drought springs

$\triangle$ Contour lines

$\wedge$ Streams

Water quality class
- I class
II class
$\checkmark$ WI class
$\times \Gamma$ class
- V class
Forest sites

$500 \quad 0$

500

$2000 \mathrm{~m}$

Map 2. Forest sites in the study area and water quality classes during snow melt 


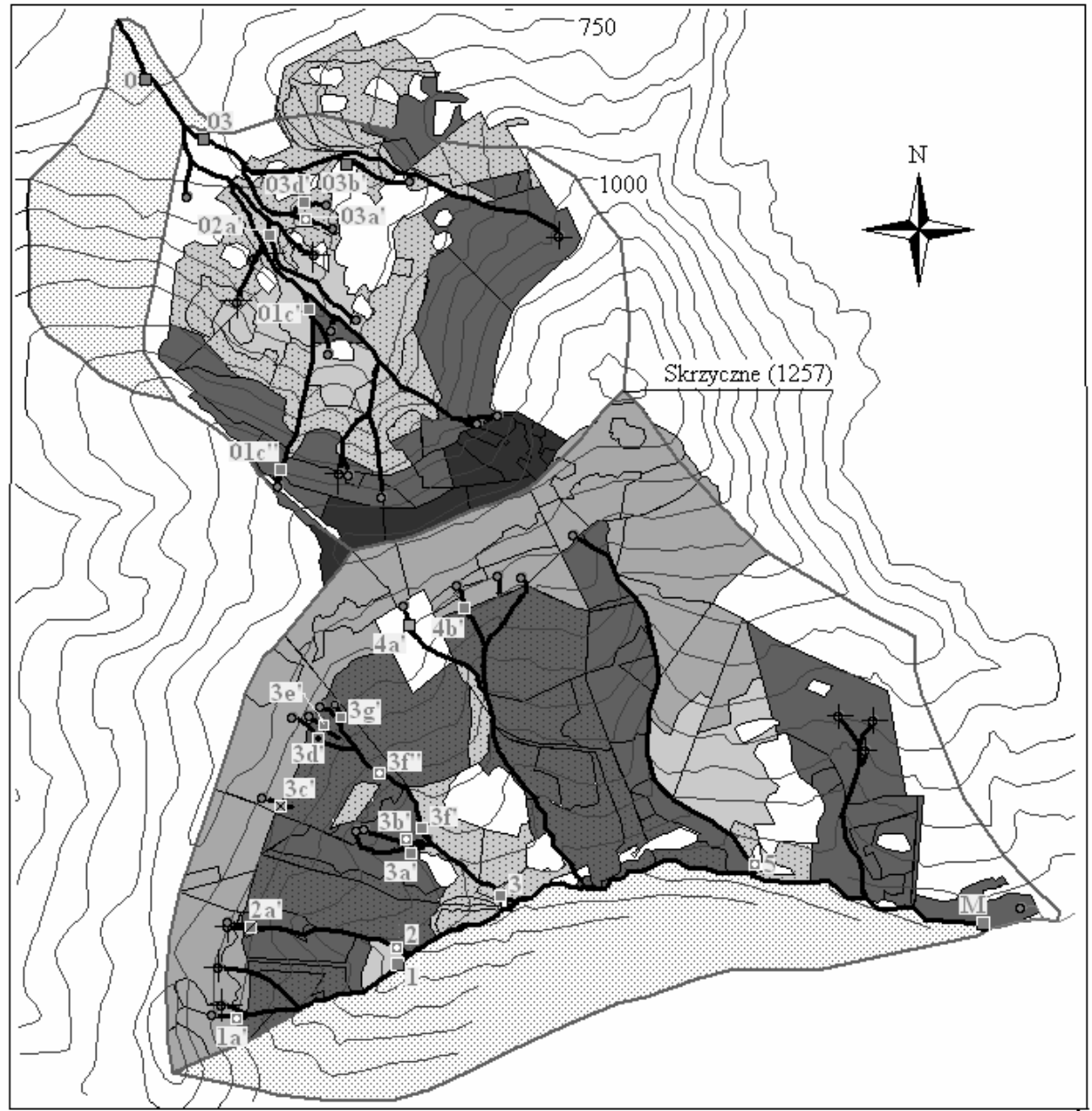

\section{Legend}
- Springs
Water quality class
- Drought springs
- I class
$\checkmark$ Contour lines
Streams
- II class
$\checkmark$ III class
$\times \Gamma$ class

- V class

\section{0}

$0 \quad 500$

1000

1500

$2000 \mathrm{~m}$

Type of forest stand

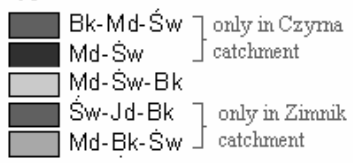

Bk - European beech

Św - Norway spruce

Md - Common larch

Jd - Silver fir

The last species is the most numerous

Map 3. Types of forest stands, site disturbance and water quality classes in the study area during low water flow 
during snowmelt (13.04.2004 and 2-4.05.2004), II - during heavy precipitation (18-20.06.2004) and III - during low water flow (15-17.10.2004).

Water samples were analysed in the chemical laboratory of the Department of Forest Ecology. $\mathrm{pH}$ of samples (pH-meter Eijkelkamp 18.37) and electrolytic conductivity - EC (conductivity meter Eijkelkamp EC 18.34) were measured before filtering the samples. Then the concentrations of: $\mathrm{Li}^{+}, \mathrm{Na}^{+}, \mathrm{NH}_{4}^{+}, \mathrm{K}^{+}, \mathrm{Ca}^{2+}, \mathrm{Mg}^{2+}$, $\mathrm{F}^{-}, \mathrm{Cl}^{-}, \mathrm{NO}_{3}{ }^{-}, \mathrm{SO}_{4}{ }^{2-}, \mathrm{PO}_{4}{ }^{3-}, \mathrm{HCO}_{3}^{-}$were analysed with the ion chromatograph Dionex -320 .

Results were elaborated in the following stages:

a) selection of samples for further analysis based on ionic balance;

b) classification of water quality acc. to the Directive of the Minister of Environment as of 11 February 2004, and Directive of the Minister of Environment as of 27 November 2002 due to examined characteristics;

c) removal from further analyses: 3d' in the first and third session, 4c', 02a', 03d', and $03 \mathrm{~b}$ ' in the third session (principle of three signs) and chemical species of too low content $\left(\mathrm{Li}^{+}, \mathrm{F}^{-}, \mathrm{NH}_{4}^{+}, \mathrm{PO}_{4}{ }^{3-}\right)$;

d) reduction of analysed chemical species - correlations between concentrations of specific ions and EC were calculated. Pearson's coefficient of linear correlation (significance level 0.05) was used. From among significantly correlated variables, strongly correlated variables $(p>0.7)$ were selected. The feature of the highest coefficient of variability was left for further analysis, i.e. in the Zimnik Catchment $\mathrm{Na}$ was left from the group of $\mathrm{Na}^{+}, \mathrm{Mg}^{2+}, \mathrm{K}^{+}$and $\mathrm{Ca}^{2+}$ from $\mathrm{Ca}^{2+}$ $\mathrm{HCO}_{3}^{-}$, in the Czyrna catchment: $\mathrm{Mg}^{2+}$ from $\mathrm{Na}^{+}, \mathrm{Mg}^{2+}$ and $\mathrm{HCO}_{3}^{-}$from $\mathrm{Ca}^{2+}$, $\mathrm{HCO}_{3}$ group;

e) analysis of correlation between the dependent variables and environmental conditions: age of the main stand density, height above sea level, soil and geological foundation, inclination and exposition of the slope, forest site, site moisture and site deformation, forest type, session;

f) in the case of correlation with continuous variables a regression analysis was performed; the remaining features were divided into groups according to assigned ranks, and in such groups the averages were compared according to the scheme in Figure 1.

\section{RESULTS AND DISCUSSION}

The layout of mountain streams in the examined basins represents two variants. The network of mountain streams in the Czyrna catchment may be described as oval, concentric with mountain streams running close to each other to the main outflow, creating a hydrological node. The network of mountain streams in the $\mathrm{Zi}$ mnik catchment has feather-like form and is extended (map 2). Comparison of the 


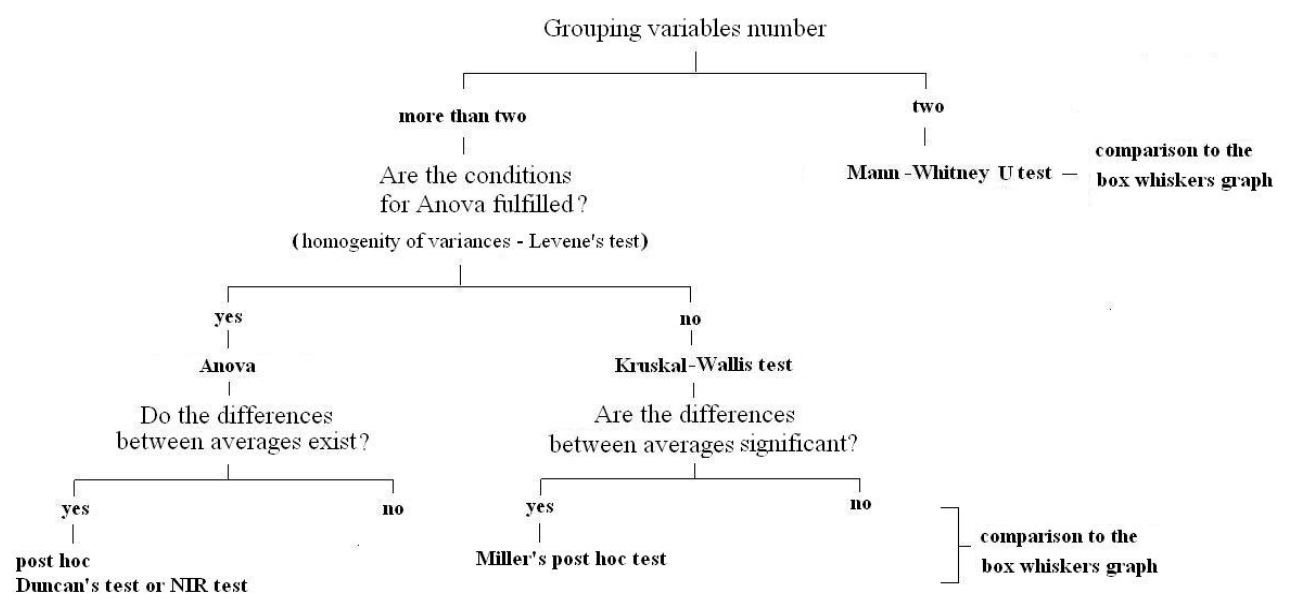

Fig. 1. Procedure concerning statistics of the grouping variables

surface and length of the two basins and the density of river network reflects described layouts (Tab. 1).

During the study we noticed periodical changes in the occurrence and location of the mountain streams (map 1-3). This is a natural phenomenon associated with general water circulation resulting from the dynamics of underground and ground water reservoirs. This dynamics may be also noticed throughout one year (MALEK and GAWĘDA, 2004; 2006a; 2006b). There is one hydro-isobath locating the groundwater table at a depth of two meters in the study area (hydrographic maps 2002). One of the examined plots (01a') is within its range. Water reservoir in the upper part of Skrzyczne depends on atmospheric precipitations. During June precipitations, even with a disappearance of some mountain streams, the density of river network was biggest, and the springs were at higher altitudes than in other sampling sessions (Tab. 1).

The majority of analysed chemical species fulfilled the norms for the I class water quality and for A1 category. High concentration of ammonium ions and nitrates and too low $\mathrm{pH}$ were the limiting factors (Tab. 2-4).

Snow melt was followed by nitrate input to streams. $\mathrm{pH}$ of examined waters was low so that most of them fell into the II class (mean pH of water in the Zimnik catchment on that sampling occasion was 5.85, and in Czyrna - 6.19; see map 2).

During intensive precipitation the water quality improved in Czyrna (average $\mathrm{pH}-6.68$; map 1), whereas in Zimnik the number of parameters with waters below the II class increased (average $\mathrm{pH}-6.10$ ) probably as a result of acidifying effect of spruce stand and outwashing of acid substances from the rock subsoil and humic acids from the surface soil layers (MACIASZEK et al., 2000). 
Table 1. Selected physiographic parameters of studied catchments

\begin{tabular}{lcc}
\hline & Zimnik catchment & Czyrna catchment \\
\hline Mean elevation, m a.s.l. & 916.24 & 930.11 \\
Area of catchment, $\mathrm{km}^{2}$ & 7.52 & 4.14 \\
Catchment's length, km & 4.73 & 2.32 \\
Terrain configuration index & 0.32 & 0.36 \\
Ordinate of the highest spring, m a.s.1. & & \\
- on hydrographical maps 2002 & $1130(4 \mathrm{a})$ & $1210(01 \mathrm{~h})$ \\
- in the study & $1130(4 \mathrm{a})$ & $1125(01 \mathrm{~h})$ \\
River network density according to Neuman, $\mathrm{km} \cdot \mathrm{km}^{-2}$ & & \\
- on hydrographical maps 2002 & 1,99 & 2.91 \\
- study maximum (June 2004) & 2.07 & 2.57 \\
- study minimum (October 2004) & 1.85 & 2.08 \\
Springs density index, amount $\cdot \mathrm{km}^{-2}$ & & \\
- on hydrographical maps 2002 & 1.73 & 3.87 \\
- in the study - all springs & 2.79 & 4.11 \\
- in the study - springs present in all sessions & 1.86 & 3.14 \\
\hline
\end{tabular}

Table 2. Mean concentrations of chemical species in sessions

\begin{tabular}{|c|c|c|c|c|c|c|c|c|c|c|c|c|}
\hline \multirow{2}{*}{ Session } & \multirow{2}{*}{$\begin{array}{c}\text { Catch- } \\
\text { ment }\end{array}$} & $\mathrm{Na}$ & $\mathrm{NH}_{4}$ & $\mathrm{~K}$ & $\mathrm{Ca}$ & $\mathrm{Mg}$ & $\mathrm{Cl}$ & $\mathrm{NO}_{3}$ & $\mathrm{SO}_{4}$ & $\mathrm{HCO}_{3}$ & \multirow{2}{*}{$\mathrm{pH}$} & $\mathrm{EC}$ \\
\hline & & \multicolumn{9}{|c|}{$\mathrm{mg} \cdot \mathrm{dm}^{-3}$} & & $\mathrm{mS} \cdot \mathrm{cm}^{-1}$ \\
\hline & Zimnik & 1.00 & 0.20 & 0.44 & 5.83 & 0.73 & 0.88 & 4.26 & 11.60 & 5.84 & 5.85 & 66.29 \\
\hline & Czyrna & 1.08 & 0.29 & 0.61 & 8.13 & 1.09 & 1.01 & 6.38 & 12.96 & 10.52 & 6.19 & 82.00 \\
\hline & Zimnik & 1.56 & 0.25 & 0.53 & 8.88 & 1.02 & 1.85 & 1.79 & 13.76 & 16.50 & 6.10 & 70.23 \\
\hline & Czyrna & 1.37 & 0.23 & 0.59 & 8.40 & 1.05 & 1.94 & 2.90 & 10.76 & 15.65 & 6.68 & 108.58 \\
\hline \multirow{2}{*}{ III } & Zimnik & 1.54 & 0.56 & 0.58 & 6.39 & 1.27 & 1.62 & 3.14 & 15.17 & 10.98 & 5.98 & 66.56 \\
\hline & Czyrna & 2.94 & 0.68 & 1.05 & 3.65 & 2.37 & 2.04 & 4.11 & 17.34 & 5.39 & 6.80 & 88.43 \\
\hline
\end{tabular}

Low water stage was still the only factor responsible for qualification of waters to the IV and V class due to low reaction (mean pH in the basin of Zimnik 5.98, in Czyrna - 6.80 - averages covering sites excluded from further analysis). In the Zimnik catchment the lowest $\mathrm{pH}$ was 4.91 in site $3 \mathrm{~d}$ '. Moreover, there were remarkably high concentrations of ammonium ions not observed in previous sessions. Their presence in the third session was connected with autumn decomposition of organic matter (Tab. 3, 4, map 3).

A substantial improvement of water $\mathrm{pH}$ in the Czyrna catchment, during intensive precipitations and at low water flow proves that low $\mathrm{pH}$ in that catchment is influenced mainly by snowmelt. The points that preserved low $\mathrm{pH}$ during all sampling sessions in the Zimnik catchment evidence that the reaction of waters did not depend exclusively on precipitation but also on permanent factors like geology and soils (ASTEL et al., 2008a; 2008b; 2009). 


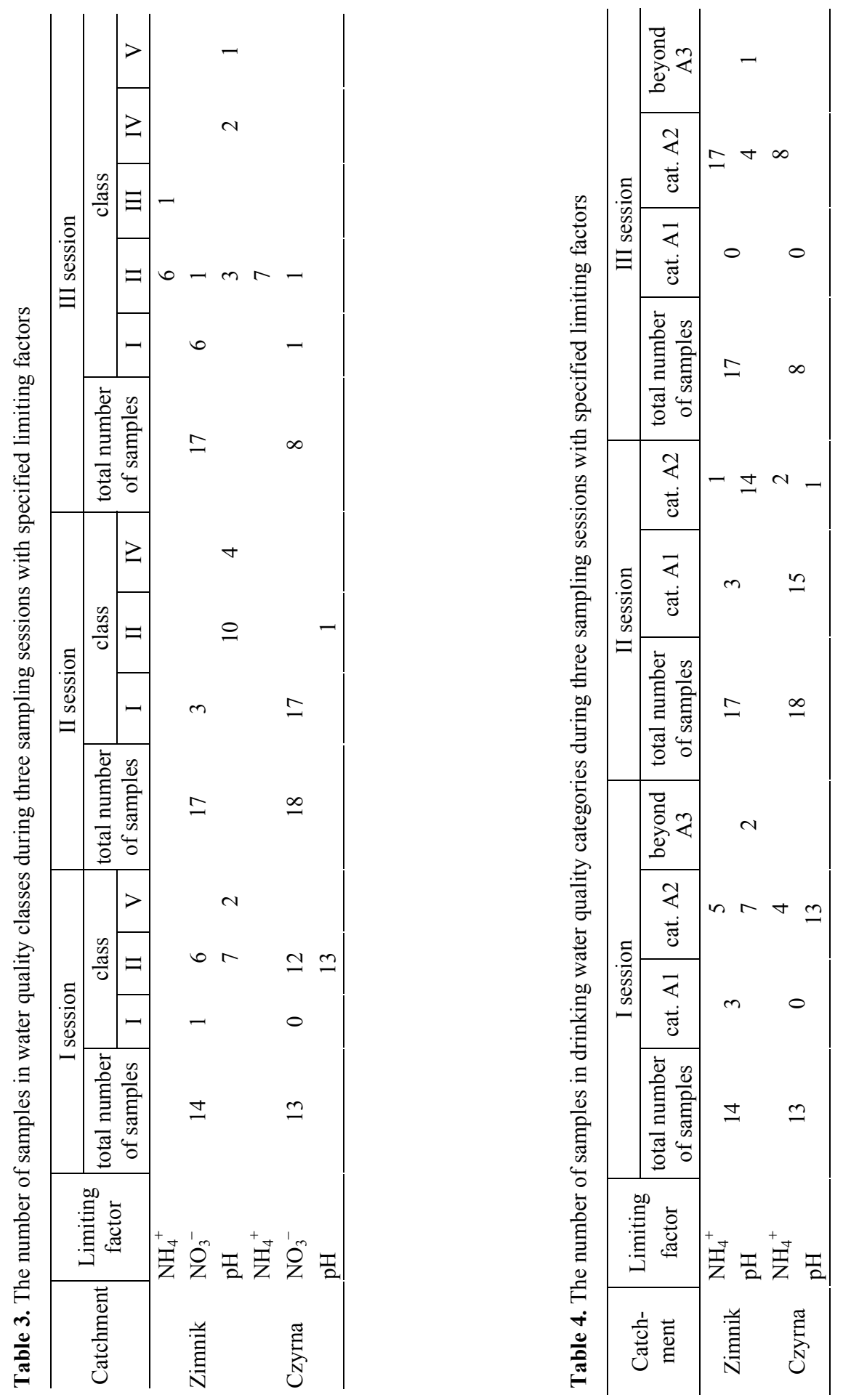


Classification of waters according to the Directive of 2002 is considerably stricter for ammonium ions whereas the allowable nitrate concentrations are higher (waters from all points fell into A1 category due to nitrogen concentration) (Tab. 3, 4).

Results of correlation analysis are presented in Tables 5 and 6 with statistically significant coefficients given in bold (data generated in Statistica software).

In the Zimnik catchment we found statistically significant relationship between: $\mathrm{SO}_{4}{ }^{2-}$ and geological sediments and session. Electrolytic conductivity was correlated with soil type and elevation above sea level, $\mathrm{Cl}^{-}$- with session and age of forest stand and $\mathrm{Na}^{+} \mathrm{Mg}^{2+}, \mathrm{K}^{+}$with geological sediments. In the Czyrna catchment we found statistical significance of correlation between: $\mathrm{SO}_{4}{ }^{2-}$ and geological sediments, EC and elevation above sea level, $\mathrm{Cl}^{-}$and slope and session; $\mathrm{Na}^{+} \mathrm{Mg}^{2+}$ and forest moisture, site degradation and forest type, $\mathrm{Ca}^{2+}, \mathrm{HCO}_{3}{ }^{-}$and age of the forest type, $\mathrm{H}^{+}$and session (Tab. 5, 6).

Correlation analysis and comparisons of averages in the groups demonstrated (Tab. 7,8$)$ that precipitation exerted the strongest influence on the chemistry of waters in mountain streams. During snow melt the reaction of waters was lowest in the Czyrna catchment - this was the consequence of snow cover acidity (MAŁEK and ASTEL 2008). The snow cover remaining in higher parts of Skrzyczne in spruce overgrown areas supplied substantial amounts of $\mathrm{NO}_{3}^{-}$. The average concentration of $\mathrm{NO}_{3}{ }^{-}$ions was higher in Czyrna $\left(6.38 \mathrm{mg} \cdot \mathrm{dm}^{-3}\right)$ than in Zimnik (4.09 $\left.\mathrm{mg} \cdot \mathrm{dm}^{-3}\right)$. This difference indicates a great significance of the slope exposition which affected precipitations and their supply to streams (Fig. 2, 3, Tab. 2).

Spatial distribution of precipitation is markedly diversified in the area of the Beskid Ślaski and depends on the elevation above sea level, on topographic profile and exposition. Annual average precipitation varies from $900 \mathrm{~mm}$ in the lower part of the site to $1400 \mathrm{~mm}$ in the summit areas. Mean long term (1961-2000) annual precipitation estimated in the Institute of Meteorology and Water Management (IMGW) in Szczyrk was $1325 \mathrm{~mm}$. The precipitation ranged from $947 \mathrm{~mm}$ in the driest year (1969) to $1816 \mathrm{~mm}$ in the most humid period (hydrographical map 2002). The dominance of westerly winds is the reason why the Czyrna catchment receives more rainfalls than the Zimnik catchment situated in the precipitation shadow. Low concentration of chlorides during snow melt, in comparison with other sampling seasons, suggests that the continental air mass dominated in winter 2004.

The highest electrolytic conductivity (mean $E C-108.6 \mu \mathrm{S} \cdot \mathrm{cm}^{-1}$ ) was estimated during intensive precipitations in the Czyrna catchment. However, no increase of examined ions was noted that could increase the value of $E C$. Therefore, the outwashing of small molecules from plants' surfaces and humus layer (humus and humic acid) rather than the release of ions from the rock subsoil was responsible for high conductivity. The lowest concentrations of $\mathrm{NO}_{3}^{-}$in the Zimnik catchment are another argument in favour of the fact that reaction in that catchment is 


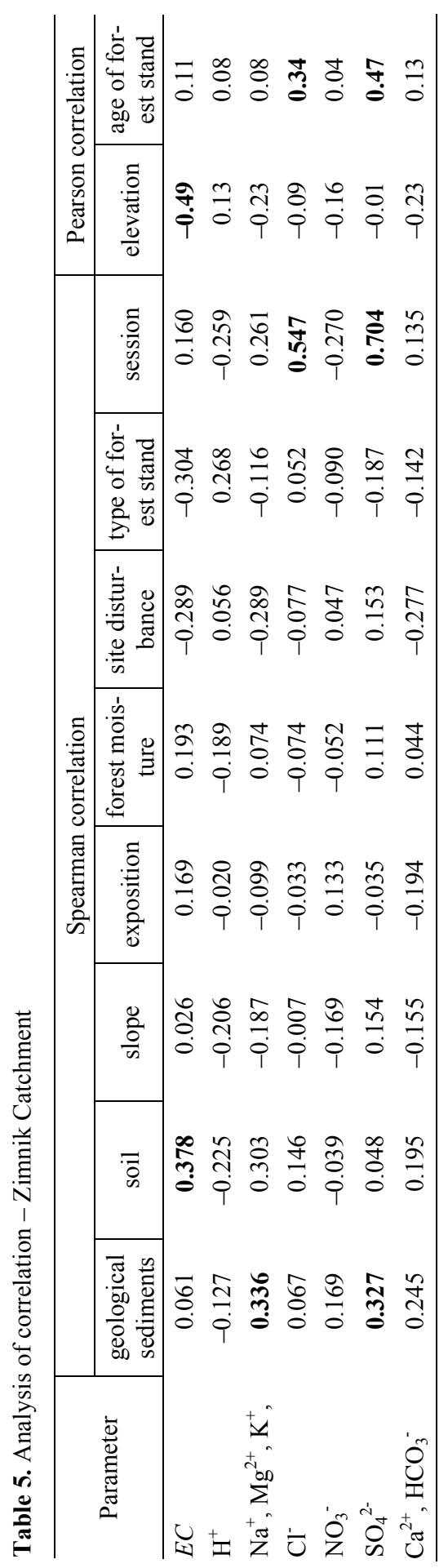

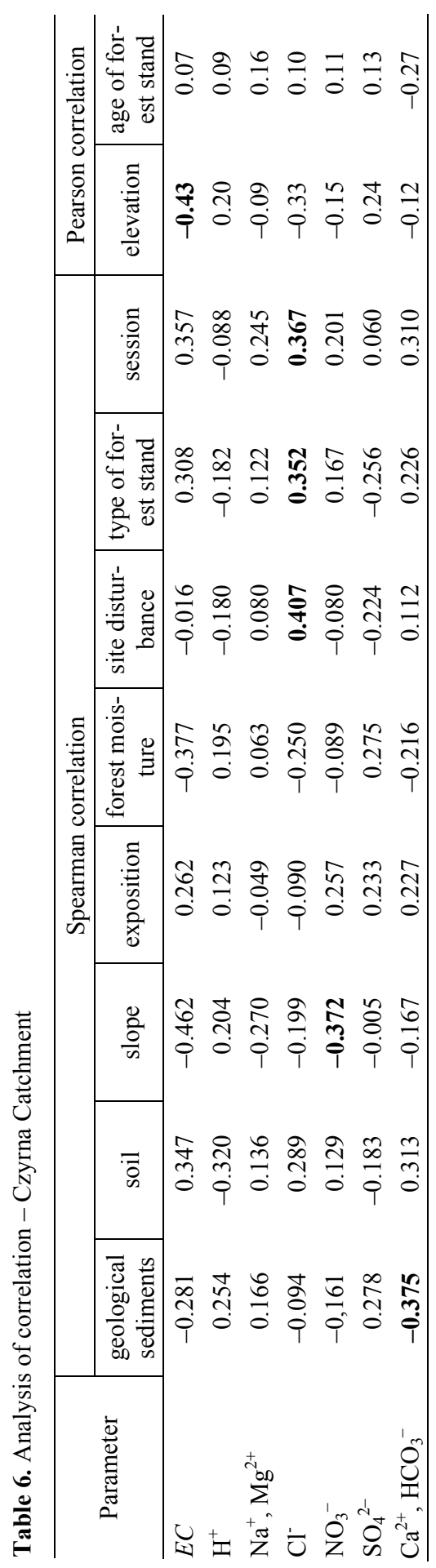




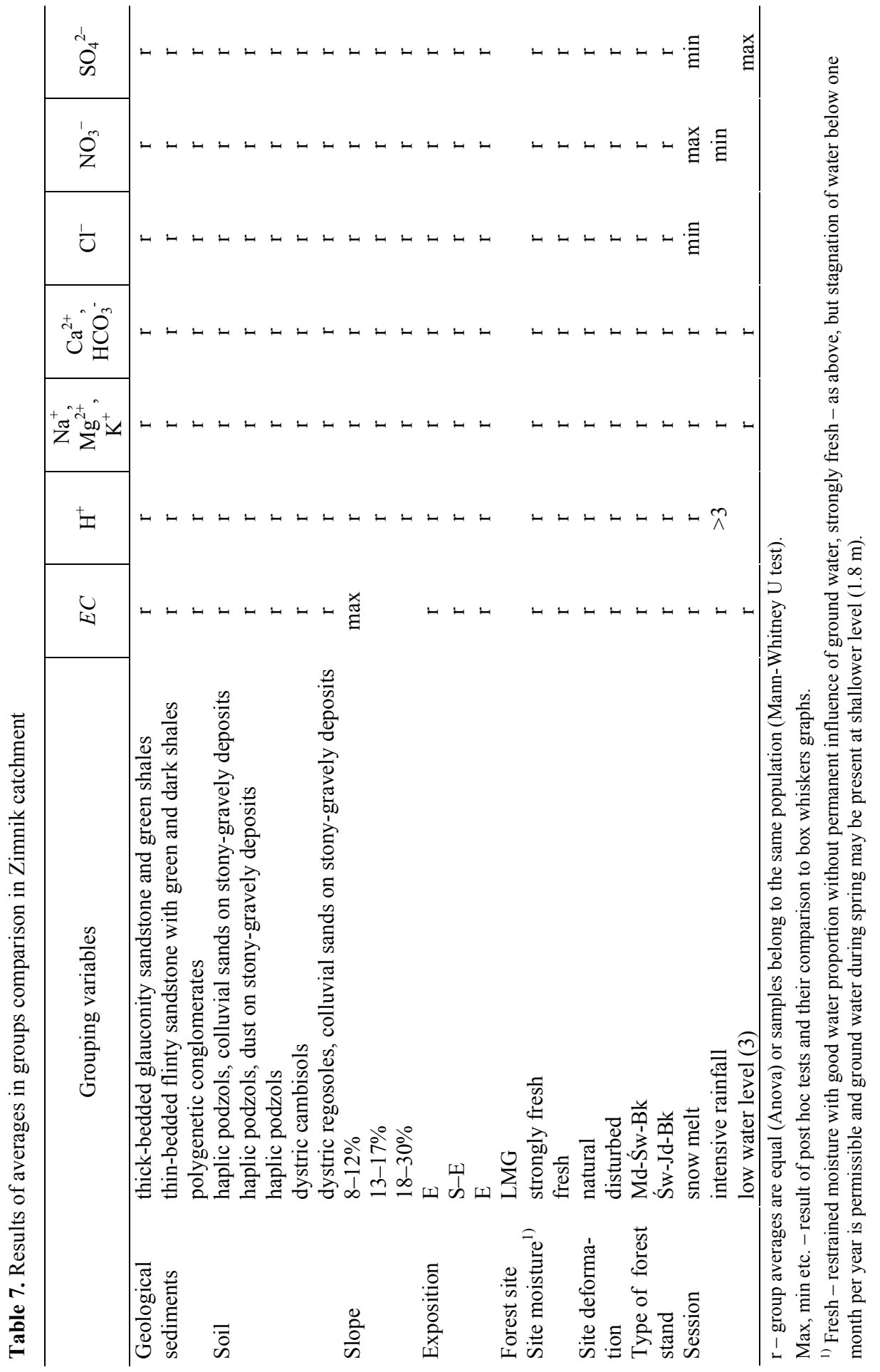




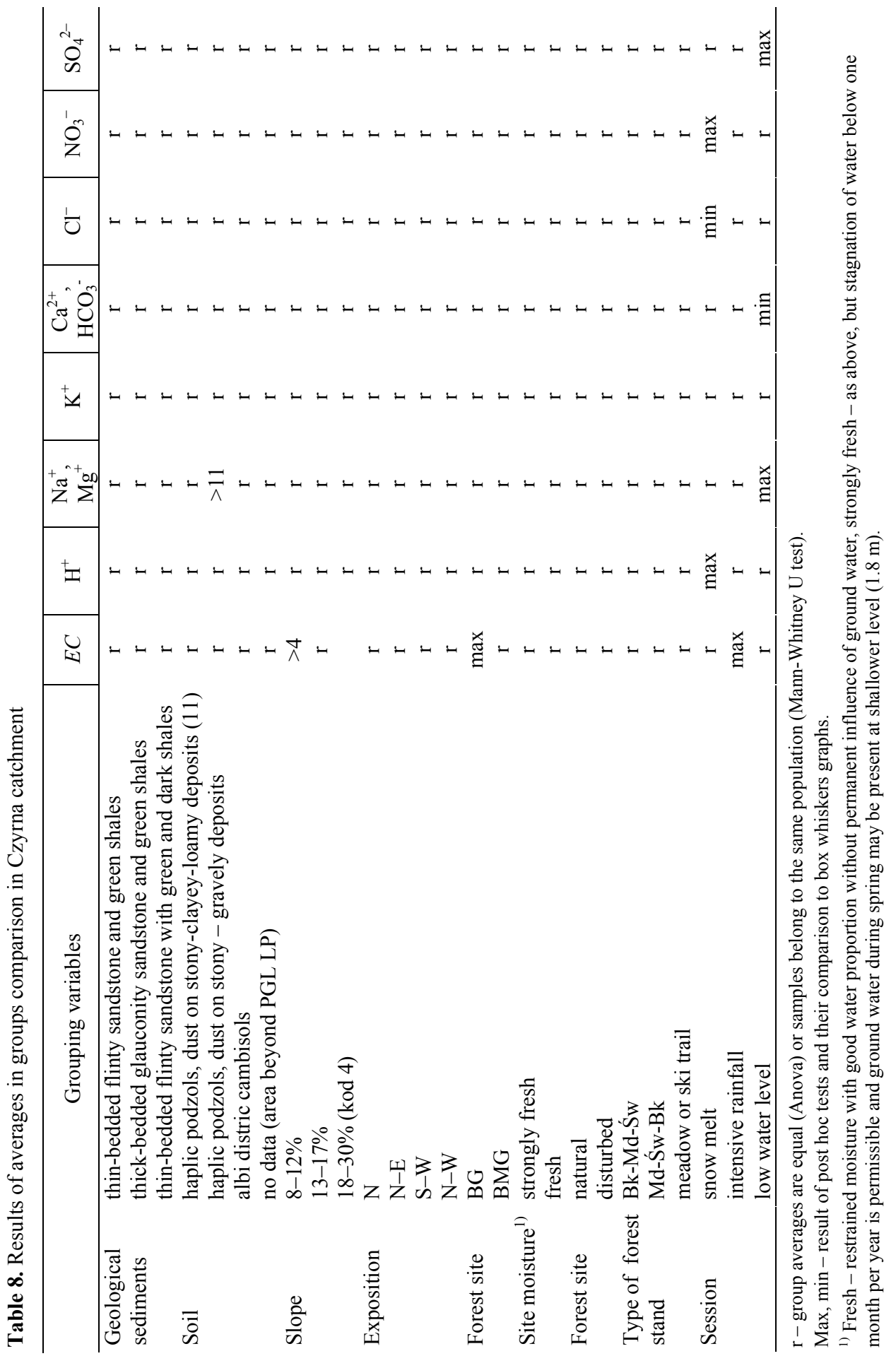



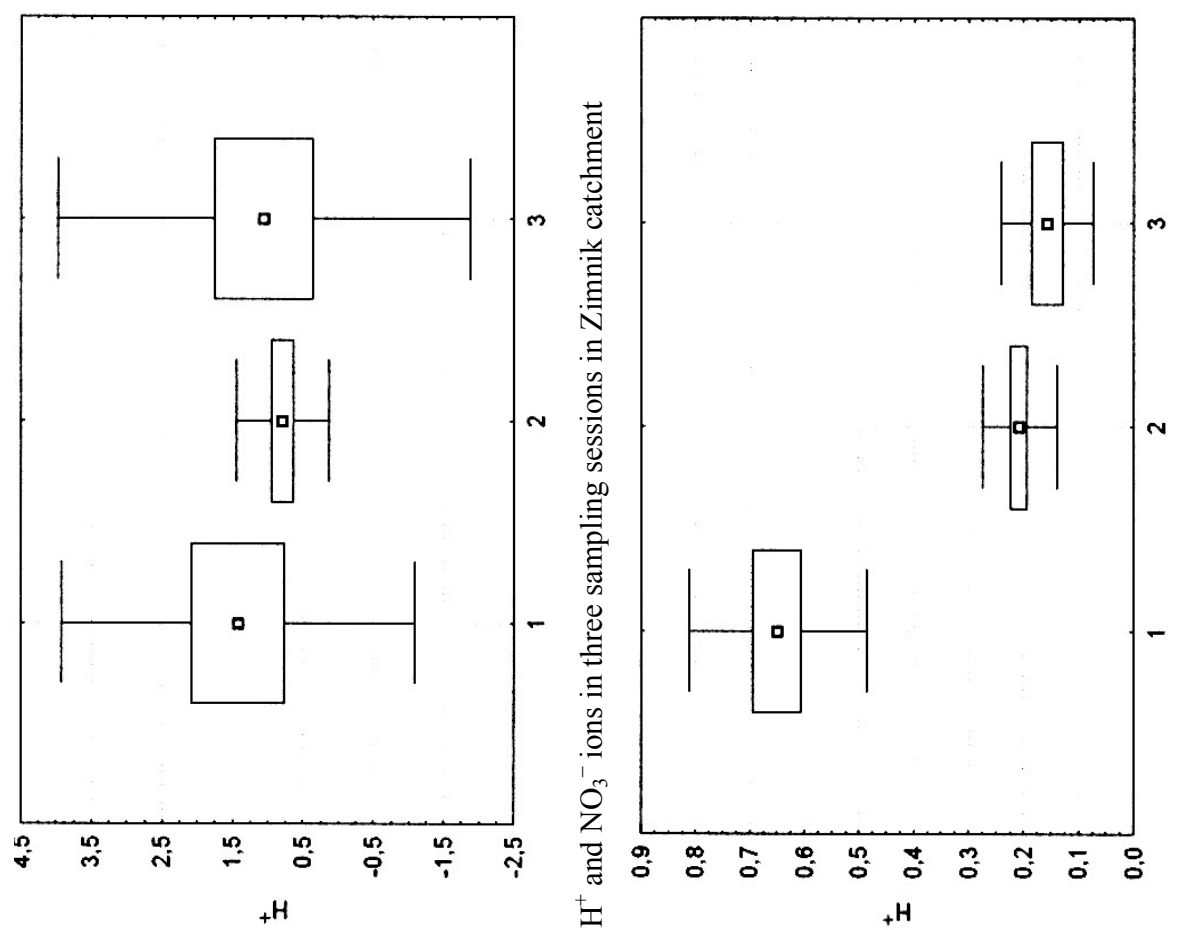

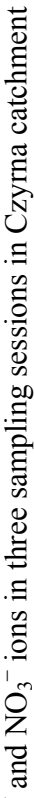

焉
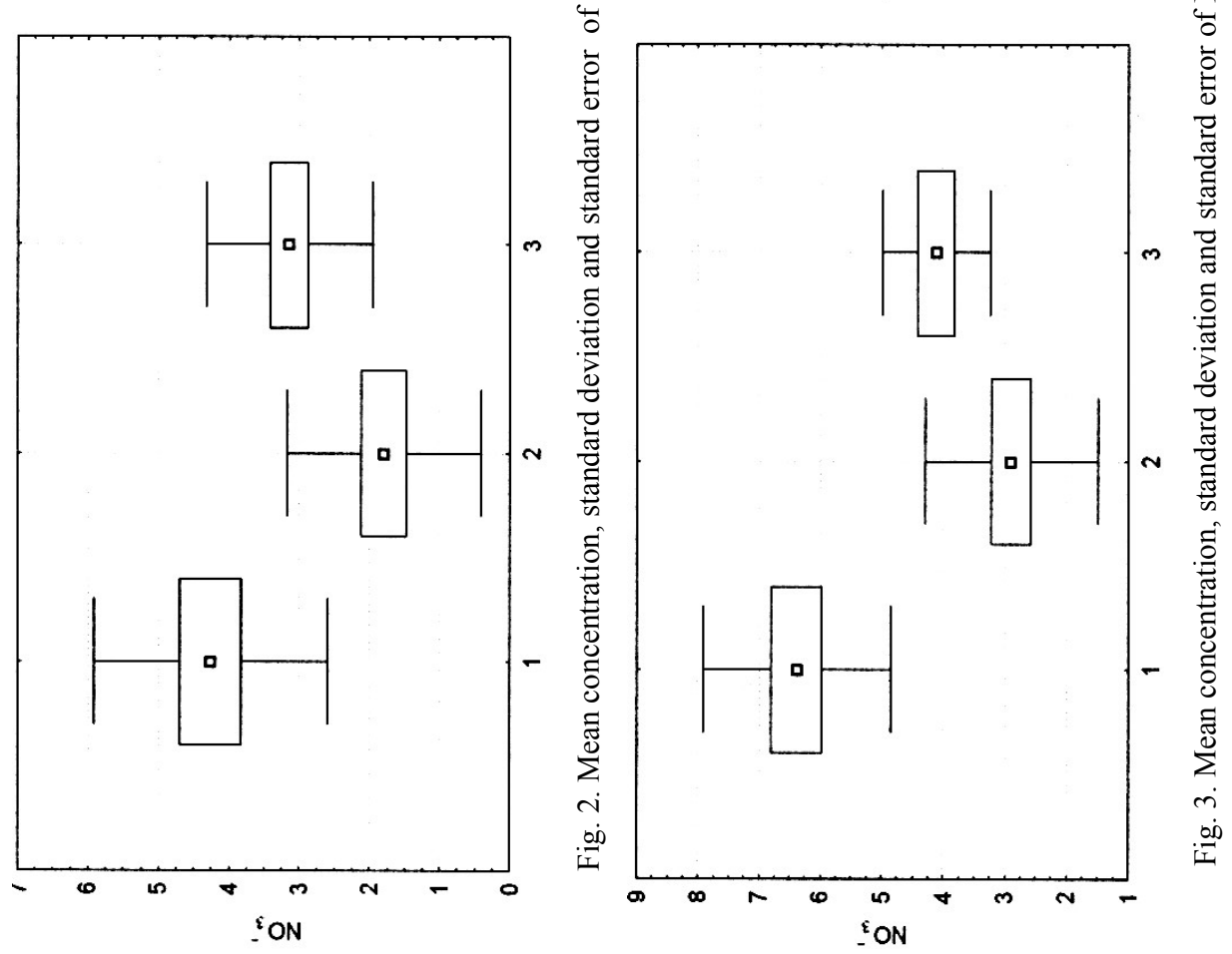
determined by the characteristics of soil and rock foundation. Low concentration of $\mathrm{NO}_{3}{ }^{-}$may be caused by a smaller input of waters from spruce stands (MAŁEK and ASTEL, 2008; ASTEL et al., 2009).

During a low water stages the highest concentration of $\mathrm{Na}^{+}$and $\mathrm{Mg}^{2+}$ ions was found in the Czyrna and of $\mathrm{SO}_{4}{ }^{2-}$ in both catchments. These results indicate a substantial outwashing of ions from the rock foundation (ASTEL et al., 2008a; 2008b; 2009).

Moreover, the lowest concentration of bicarbonates and calcium ions was noted in the Czyrna catchment.

The remaining variables affected water chemistry in Czyrna in various ways. The highest $E C$ was noted in points at the slopes of the smallest inclination, which may be explained by accumulation of ions where the water flow diminishes. Lower concentrations of $\mathrm{Mg}^{2+}$ and $\mathrm{Na}^{+}$were noted in disturbed than in natural sites. Probably, this resulted from a higher content of these ions in deciduous trees (beech, sycamore) than in stand dominated by spruce (MACIASZEK et al., 2000; ASTEL et al., 2008a; 2008b; 2009). No statistically significant differences in chemical characteristics of environment features connected with flora (forest site, its deformation, type of forest stand) were noted in the Zimnik catchment.

It is worth looking closer on the protruding points that were not qualified for further measurements but no error was found in the measurement of their features (items fulfilling ions balance conditions). In the Zimnik catchment, we found point $3 \mathrm{~d}^{\prime}$ during the first and third session and $4 \mathrm{c}^{\prime}$ in the first session. Water from these sites had a very low $\mathrm{pH}$ of 5.14, 4.91, and 5.13, respectively. Following previously mentioned line of evidence, a low reaction of these waters may be a result of washing out of acid substances from the rock foundation and humus and humic acids from decaying spruce litter, and in the first session - also from inflow of nitrogen from the snow melt. A slightly higher $\mathrm{pH}$ in site $3 \mathrm{~d}$ ' during precipitation (5.51) may result from dilution of these substances by rain water. Undoubtedly, in this place there were specific local conditions; also other points located in similar environment, not indicating such deviations, underwent the examination.

In the Czyrna catchment, the protruding points had a slightly opposite character. $02 \mathrm{a}$ ', $03 \mathrm{~d}$ ', and $03 \mathrm{~b}$ ' were characterised in the third session by high concentration of $\mathrm{Mg}^{2+}$, and $03 \mathrm{~b}$ ' also by high $\mathrm{Na}^{+}$. These ions may come from two sources. The first is the release of cations form the rock foundation (all sites are in the range of substantially fertile brown podzoil soils). Higher concentration of magnesium and sodium could indirectly result from the decay of leaf litter (beech, sycamore) in tree stands neighbouring the described sites and affecting stream waters. The decay of litter has an important influence on chemical characteristics of water, which may be demonstrated by an increase of $\mathrm{NH}_{4}{ }^{+}$concentration during the October session. 


\section{SUMMARY AND CONCLUSIONS}

Chemical composition of stream waters located in the Zimnik and Czyrna catchments depends on physico-geological constitution of drainage areas and on seasonal changes of water stage in the catchment. The dying out of spruce in the Beskid Śląski influenced the quality of waters in streams running along the slopes of Skrzyczne. Most important for water chemistry is the air pollution supplied to stand with precipitations and species composition of tree stands. A crucial moment is the snowmelt period when contamination is delivered to forest ecosystems in a concentrated form.

The main factor that makes waters at Skrzyczne unsuitable for drinking purposes is low reaction of waters and a high concentration of nitrate and ammonium ions. A regular consumer of these waters does not have the possibility to evaluate water quality in streams that one might get across. Water quality depends not only on easily visible reasons of its possible deterioration (spruce stand composition, snowmelt period) but also on local conditions. Water quality differed during intensive rainfalls when in the Czyrna catchment 15 out of 18 samples reached the highest A1 category (suitable for drinking) while in the Zimnik catchment such category was achieved by only 3 out of 17 samples.

Chemical features of water may to some degree be modified through structuring the composition of tree stand, which was confirmed by higher concentration of magnesium and sodium ions in waters from sites neighbouring multi-species deciduous tree stands (beech, sycamore). Therefore, it is necessary to elaborate rules and principles of managing spring areas, particularly in the regions from where water is intended to be taken for drinking purposes.

\section{REFERENCES}

1. Astel A., MaŁeK S., Makowska S., 2008a. Linear discriminant function analysis in assessment of chemical profiles for Black and White Vistula rivers in "Barania Góra" sanctuary forest area (Poland, Silesian Beskid). Water Air Soil Pollut., 195: 137-149.

2. Astel A., MaŁeK S., Krakowian K., 2008b. Sustainable afforestation as a tool of spring water sources protection in the mountain ekosystem. Polish J. Envir. Stud., 17, 3A: 22-27.

3. Astel A., MaŁeK S., Krakowian K., 2009. Multivariate exploration and classification applied to the chemical composition of spring waters in sanctuary forest areas. Intern. J. Env. Analyt. Chemistry. (ID GEAC-2008-0232.R2).

4. Plan urządzania lasu dla LKP Lasy Beskidu Śląskiego, Nadleśnictwa Bielsko na okres od 01.01.1998 do 31.12.2007. Opisanie ogólne. Cz. tabel. cz. opis., 1998.

5. Plan urządzania lasu dla LKP Lasy Beskidu Śląskiego, Nadleśnictwa Węgierska Górka, Obrębu Lipowa na okres od 01.01.2004 do 31.12.2013. Opisanie ogólne. Cz. opis. Program dla Beskidów, Katowice. 2003.

6. CheŁmicki W., Baścik M., Korska A., Pociask-Karteczka J., Siwek J., Żelazny M., 2001. Porównanie stanu źródeł wyżyn Krakowsko-Wieluńskiej i Miechowskiej w latach 1973-1974 i 1999- 
-2000. W: Przemiany środowiska a jego funkcjonowanie. Red. K. German, J. Balon. Probl. Ekol. Krajobr., 10: 383-388.

7. Dorda A., 2004. Barania Góra - Rezerwat krajobrazowy u źródeł Wisły (50-lecie utworzenia rezerwatu). Przyroda Górnego Śląska, 38: 8-9.

8. DynOwSKA I., 1986. Regionalne zróżnicowanie źródeł w Polsce. Folia Geogr. Ser. Geogr. Phys., 18: 5-30.

9. KONDRACKI J., 2000. Geografia regionalna Polski. Warszawa, PWN.

10. Kostarkiewicz L., 2001. Sezonowa zmienność chemizmu wód powierzchniowych w okresie posuchy atmosferycznej na terenie Ojcowskiego Parku Narodowego i jego otuliny. W: Badania naukowe w południowej części Wyżyny Krakowsko-Częstochowskiej. Red. J. Partyka. Ojców, Ojcowski Park Narodowy: 61-63.

11. Maciaszek W., Gruba P., JanuszeK K., Lasota J., Wanic T., ZwydaK M., 2000. Degradacja i redegradacja gleb pod wpływem gospodarki leśnej na Terenie Żywiecczyzny. Kraków, Wydaw. AR.

12. MaŁek S., GawędA T., 2002. Chemizm wód Potoku Dupniańskiego w Beskidzie Śląskim. Inż. Środ., 4: 85-94.

13. MAŁeK S., GAWĘDA T., 2004. Charakterystyka chemiczna wód powierzchniowych zlewni Potoku Dupniańskiego oraz Olzy w Beskidzie Śląskim. Zesz. Nauk. UZiel., 131, 12: 257-264

14. MAŁeK S., GAwĘDA T. 2006a. Charakterystyka chemiczna wód powierzchniowych zlewni Potok Dupniański w Beskidzie Śląskim. Sylwan, 2: 29-36.

15. MAŁeK S., GawĘDA T. 2006b. Charakterystyka chemiczna źródeł Potoku Dupniańskiego w Beskidzie Śląskim. Sylwan, 3: 39-46.

16. Matek S., Krakowian K. 2007. Charakterystyka chemiczna wód źródeł Malinowskiego Potoku i Czyrnej w Beskidzie Śląskim. Funkcjonowanie geoekosystemów zlewni rzecznych. T. 4. Poznań, Bogucki Wydaw. Nauk.: 331-344.

17. MAŁEK S., ASTEL A., 2008. Throughfall chemistry in a spruce chronosequence in southern Poland. Env. Pollut., 155: 517-527.

18. MichalCZYK Z., 2001. Źródła Wyżyny Lubelskiej i Roztocza. Lublin, UMCS: 298.

19. MunK L.A. FAURE G., 2004. Effects of pH fluctuations on potentially toxic metals in the water and sediment of the Dillon Reservoir, Summit County, Colorado. Appl. Geochem, 19(7): 1065-1074.

20. Pacholewski A., Liszka P., GuZiK M., Zembal., PAsZeK L. 2004. Informacja o jakości wód podziemnych w województwie Śląskim w 2004 roku http://bip.katowice.pios.gov.pl

21. Rozporządzenie Ministra Środowiska z dnia 11 lutego 2004 r. w sprawie klasyfikacji dla prezentowania stanu wód powierzchniowych i podziemnych, sposobu prowadzenia monitoringu oraz sposobu interpretacji wyników i prezentacji stanu tych wód. Dz. U. 2004 nr 32 poz. 284.

22. Rozporządzenie Ministra Środowiska z dnia 27 listopada 2002 r. w sprawie wymagań, jakim powinny odpowiadać wody powierzchniowe wykorzystywane do zaopatrzenia ludności w wodę przeznaczoną do spożycia. Dz. U. 2002 nr 204 poz. 1728.

23. SiKorSKa E., 2002. Siedliska leśne. Cz. 2. Siedliska obszarów wyżynnych i górskich. Kraków, Wydaw. AR: 61-63.

24. SiweK J., 2004. Źródła w zlewniach Prądnika, Dłubni i Szreniawy. Naturalne i antropogeniczne uwarunkowania jakości wód. Kraków, UJ. IGiGP: 99.

25. SzCZĘSNY B., ZięBA D., 2001. Chemical contents of water the Babia Góra Mountain (southern Poland). Nature Conserv., 58: 109-118.

26. Trudgill S.T., Pickles A.M., Burt T.P., Crabtree R.W., 2006. Eur. J. Soil Sci, 32(3): 433-441.

27. WiLCZEK Z, 1995. Zespoły leśne Beskidu Śląskiego i zachodniej części Beskidu Żywieckiego na tle zbiorowisk leśnych Karpat Zachodnich. Pr. Nauk. UŚl. 1490.

28. Wrobel S., 1998. Environmental degradation in the Czarna Wisełka and Biała Wisełka catchments. Western Carpathians. St. Nat., 44: 81-100.

29. ZDANOwICZ A. 1994. Rola zlewni rolniczej i leśnej w transporcie biogenów (azotanów i fosforanów) do strumienia. Wiad. Melior., 2: 72-75. 
30. ŻMUDA R., 1994. Wymywanie składników chemicznych z obszaru dwóch zlewni rzecznych o różnym użytkowaniu. Rocz. AR Pozn., 266, 14: 171-176.

31. Mapy hydrograficzne, 2002. Nowak A. M-34-57-A Węgierska Górka, Lęcznar G. M-34-86-B Wisła, Muskalska A. M-34-74-D Skoczów, M-34-75-C Bielsko-Biała; Częstochowa.

\section{STRESZCZENIE}

\section{Wpływ warunków środowiskowych na jakość wód powierzchniowych w zlewni Zimnika i Czyrnej w Beskidzie Śląskim}

Słowa kluczowe: Beskid Ślaski, budowa geologiczna, jakość wód, skład gatunkowy, typ siedliskowy lasu, wody powierzchniowe

Badania zostały przeprowadzone w 2004 roku w zlewniach Zimnika i Czyrnej leżących na przeciwległych stokach Skrzycznego w Beskidzie Śląskim. Analizie poddano wody pobrane $\mathrm{z}$ potoków podczas trzech sesji pomiarowych. Pierwsza odbyła się podczas roztopów śniegu (kwiecień/maj), druga sesja w trakcie intensywnych opadów deszczu w okresie wegetacji (czerwiec), trzecia przy niskim stanie wód (październik). Analizowano odczyn i przewodność elektrolityczną, oraz stężenie anionów $\left(\mathrm{Cl}^{-}, \mathrm{NO}_{3}{ }^{-}, \mathrm{SO}_{4}{ }^{2-}\right)$ i kationów $\left(\mathrm{NH}_{4}^{+}, \mathrm{Na}^{+}, \mathrm{K}^{+}, \mathrm{Ca}^{2+}, \mathrm{Mg}^{2+}\right)$. Wyniki poddano klasyfikacji wód pitnych wg polskich norm (z 2002 i 2004 r.). Skład chemiczny wód powierzchniowych zależy od fizycznych i geologicznych właściwości utworów budujących zlewnie. Przynależność wód do klasy zależy również od wystapienia i rodzaju opadów atmosferycznych oraz składu gatunkowego. Stwierdzono niezdatność dużej części badanych wód do picia - 66 z 89 pobranych prób znajdowało się poza klasa A1, głównie ze względu na niski ich odczyn oraz wysokie stężenie $\mathrm{NH}_{4}{ }^{+} \mathrm{i} \mathrm{NO}_{3}{ }^{-}$. W drzewostanach bukowych i wielogatunkowych zaobserwowano znacząco większe niż w świerkowych wymywanie kationów podczas intensywnych opadów deszczu, co w pewnym stopniu neutralizowało odczyn wód a tym samym podnosiło jakość wód. Ten fakt powinien być brany pod uwage przy zalesianiu terenów źródliskowych i sąsiadujących z potokami w obszarach, gdzie wody te wykorzystywane są lub będą w przyszłości, jako dodatkowe ujęcia wód pitnych.

Reviewers:

Prof. Nicolas Clarke

Prof. Stanistaw Niemtur 